\title{
Multidrug resistance in tumour cells: characterisation of the multidrug resistant cell line K562-Lucena 1*
}

\author{
VIVIAN M. RUMJANEK ${ }^{1}$, GILMA S. TRINDADE ${ }^{2}$, KAREN WAGNER-SOUZA ${ }^{1}$, \\ MICHELE C. MELETTI-DE-OLIVEIRA ${ }^{1}$, LUIS F. MARQUES-SANTOS ${ }^{1}$, RAQUEL C. MAIA $^{3}$ \\ and MÁRCIA A. M. CAPELLA ${ }^{1,2}$ \\ ${ }^{1}$ Departamento de Bioquímica Médica, Instituto de Ciências Biomédicas \\ Federal University of Rio de Janeiro, Rio de Janeiro, Brazil \\ ${ }^{2}$ Instituto de Biofísica Carlos Chagas Filho, Federal University of Rio de Janeiro, Rio de Janeiro, Brazil \\ ${ }^{3}$ Serviço de Hematologia, National Cancer Institute, Rio de Janeiro, Brazil
}

Manuscript received on October 25, 2000; accepted for publication on November 1, 2000; contributed by VIVIAN M. RUMJANEK**

\begin{abstract}
Multidrug resistance to chemotherapy is a major obstacle in the treatment of cancer patients. The best characterised mechanism responsible for multidrug resistance involves the expression of the MDR-1 gene product, P-glycoprotein. However, the resistance process is multifactorial. Studies of multidrug resistance mechanisms have relied on the analysis of cancer cell lines that have been selected and present cross-reactivity to a broad range of anticancer agents. This work characterises a multidrug resistant cell line, originally selected for resistance to the Vinca alkaloid vincristine and derived from the human erythroleukaemia cell K562. This cell line, named Lucena 1, overexpresses P-glycoprotein and have its resistance reversed by the chemosensitisers verapamil, trifluoperazine and cyclosporins A, D and G. Furthermore, we demonstrated that methylene blue was capable of partially reversing the resistance in this cell line. On the contrary, the use of 5 -fluorouracil increased the resistance of Lucena 1. In addition to chemotherapics, Lucena 1 cells were resistant to ultraviolet A radiation and hydrogen peroxide and failed to mobilise intracellular calcium when thapsigargin was used. Changes in the cytoskeleton of this cell line were also observed.
\end{abstract}

Key words: multidrug resistance, leukaemia, P-glycoprotein, chemosensitisers.

\section{INTRODUCTION}

Resistance to chemotherapy is a major obstacle in the treatment of cancer patients. Multiple mechanisms contribute to the overall clinical resistance to cancer chemotherapy and, although investigators have examined the putative major site of drug action as the most likely site to be involved in drug resistance, it became clear that a number of patients

\footnotetext{
*Invited paper

** Member of Academia Brasileira de Ciências

Correspondence to: Vivian M. Rumjanek

E-mail: vivian@bioqmed.ufrj.br
}

could exhibit cross-resistance to structurally unrelated drugs that did not share a common target. This phenomenon of multidrug resistance (MDR) may also result from a variety of cellular mechanisms such as: defects in the regulation of genes controlling apoptosis, enhanced intracellular drug detoxification, alterations in DNA repair, activation or overexpression of drug export proteins.

Among the various mechanisms identified with the MDR phenotype, the best characterised involves the expression of the MDR-1 gene product, P-glycoprotein (Pgp) (Gottesman \& Pastan 1993, Juranka et 
al. 1989). Transfection studies indicated that MDR1 gene overexpression is sufficient to confer multidrug resistance (Gros et al. 1986). Pgp as well as the MDR-related protein (MRP) (Cole et al. 1992, Cole et al. 1994) and the transporter of antigenic peptides (TAP) (Neefjes et al. 1993), all involved in the MDR phenotype, are members of the adenosine triphosphate (ATP)-binding cassette (ABC) supergene family that encodes ATP-dependent transmembrane transporter proteins (Higgins 1992). Cells overexpressing Pgp display a reduced intracellular concentration of the drugs that are substrates for this transporter. The Pgp drug efflux pump is capable of extruding a wide variety of structurally unrelated drugs taken up by cells through passive diffusion and, as a result, the drug intracellular level does not reach a toxic concentration (Juliano \& Ling 1976). Not only chemotherapics but a number of substances may be inhibited of accumulating inside the cell, including certain fluorescent dyes and this property is used to ascertain the functional activity of the pump (Neyfakh 1988, Pétriz \& Garcia-López 1997). Similar to Pgp, MRP is also capable of extruding various substances but in this case there is a preferential transport of substrates conjugated with glutathione (Cole et al. 1994, Muller et al. 1994). Another transporter associated with the MDR phenotype is the lung resistance-protein (LRP) that is implicated in nuclear-cytoplasmic trafficking of several substrates. This protein is capable of redistribute drugs from the nucleus to the cytoplasm and in this way confers resistance to DNA-binding drugs (Scheffer et al. 1995). Unlike MDR-1 and MRP genes, transfection of the LRP gene alone is not sufficient to confer a MDR phenotype (Scheffer et al. 1995).

Most studies attempting to circumvent MDR focused on the possibility of modulating Pgp activity. This can be achieved and a number of drugs known as chemosensitisers, Pgp modulators or reversors, have been described (Ford \& Hait 1990, Boer \& Gekeler 1995). MDR reversal through inhibition of Pgp was first obtained in vitro using verapamil (Tsuruo et al. 1981). A variety of other totally unrelated substances such as cyclosporins, phenothiazines, antimalarials, antibiotics etc. where also shown to exert a modulatory effect. To avoid toxicity resulting from the use of high doses, due to the lack of binding specificity of these drugs to Pgp, analogues of these substances, as well as new compounds, were produced and selected for their MDR reversal capabilities. A number of secondand third-generation Pgp modulators are being evaluated, but despite the efforts neither their binding sites on Pgp nor their mode of action as modulators are clearly comprehended. Recent clinical trials have evidenced that elimination of $\mathrm{Pgp}^{+}$cells through the combined use of chemotherapics and Pgp-modulators may lead to the selection of cells presenting alternate MDR mechanisms (List et al. 1993).

Approaches to study MDR mechanisms have relied on the analysis of cancer cell lines that have been selected for resistance to specific anticancer drugs and presented, at the end of the selective process, cross-reactivity to a broad range of unrelated anticancer agents (Dalton 1997). However, despite the fact that these cell lines present a MDR phenotype, these types of studies have shown that the mechanism of acquired drug resistance in cultured cell lines is dependent on the cytotoxic drug used to select the cells and the stage of the selective process they are in (Yanovich et al. 1989, Matsumoto et al. 1997, Modrak et al. 1997, Denis-Gay et al. 1998). The present work describes the characteristics of a MDR cell line derived from the human erythroleukaemia cell K562 and selected for resistance to the Vinca alkaloid vincristine (VCR).

\section{CHARACTERISATION OF THE MDR PHENOTYPE}

An approach to improving our understanding of the MDR mechanisms involved the establishment of a human MDR cell lineage based on the technique described by Tsuruo et al. (1983). Basically K562 cells were exposed by us to gradually increasing doses of VCR, starting at 3nM and augmenting the doses every two weeks by increments of $3 \mathrm{nM}$ until cells were resistant to 60nM VCR (Rumjanek et 

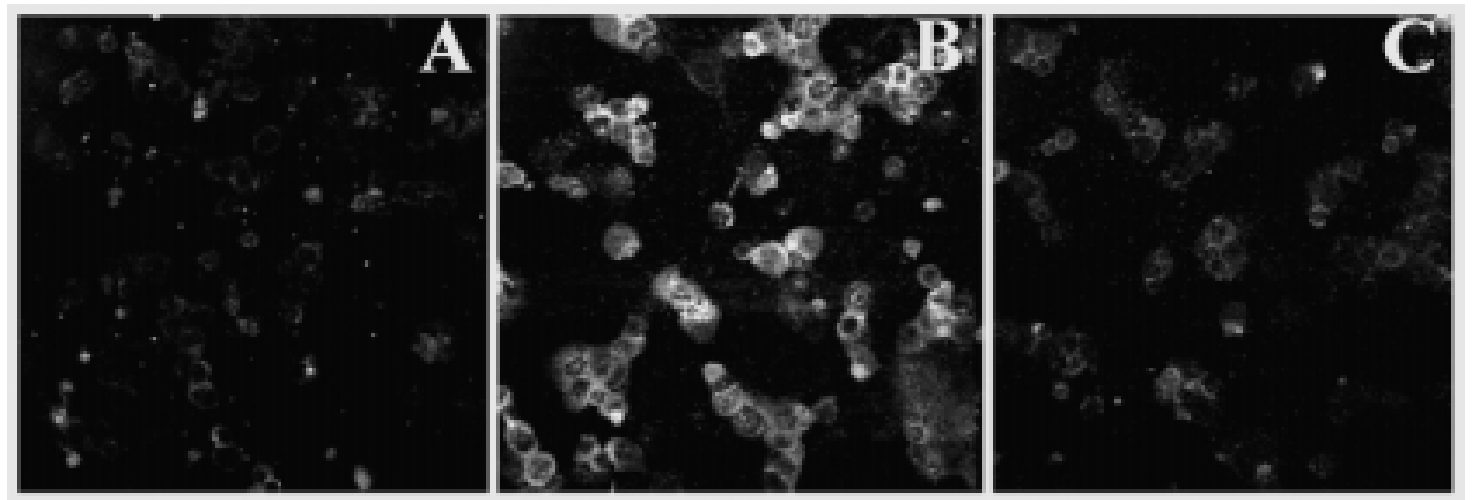

Fig. 1 - Expression of Pgp and MRP1 in Lucena 1 cells. Cells were fixed with methanol/acetone, permeabilised with $0.1 \%$ triton X-100 and incubated overnight with anti-Pgp or anti-MRP1 antibodies. After washing, cells were incubated for $2 \mathrm{~h}$ with secondary antibody labelled with FITC and the fluorescence observed under a confocal microscope (Zeiss, Germany). A - control (secondary Ab); B - cells labelled with mAb anti-Pgp; C - cells labelled with mAb anti-MRP1.

al. 1994). These VCR resistant cells, known as K562-Lucena 1, can now be cultured equally well in medium containing $60 \mathrm{nM}$ VCR as in drug-free medium.

The MDR-1 gene is amplified in Lucena 1 cells that present five times more copies of this gene when compared to the parental cell line K562 (Brindeiro 1999). Similarly, there is an overexpression of this gene as detected by RT-PCR (Brindeiro 1999). This is accompanied by the expression of Pgp on the plasma membrane of Lucena 1 cells as evidenced by immunofluorescence (Fig. 1), immunocytochemistry, or western blot using the JSB-1 anti-Pgp antibody. Furthermore, the Pgp present in these cells is functionally active, being capable of extruding the fluorescent dye rhodamine 123 (Rho 123) as assessed by flow cytometry (Fig. 2A and Fig. 2D). Because Rho 123, albeit to a lesser extent, is a substrate for MRP, the expression of this protein in Lucena 1 cells was investigated by indirect immunofluorescence using the MRPr1 anti-MRP antibody and was found absent (Fig. 1). Furthermore, no increase in glutathione $\mathrm{S}$ transferase was observed in these cells.

As should be expected in a cell line expressing functionally active Pgp, Lucena 1 cells were resis- tant to chemically unrelated chemotherapics such as anthracyclines (Maia et al. 1996a). Moreover, their resistance could be reversed by the "classical" MDR-modulators: cyclosporin A (CSA), verapamil (VP) and trifluoperazine (TFP) (Fig. 3) (Rumjanek et al. 1994). Similarly, the CSA analogues CSD and CSG, already described as having chemosensitiser properties (Mizuno et al. 1992, Tanaka et al. 1996), were also capable of reversing resistance in Lucena 1 cells (Fig. 4). It was also possible to demonstrate that methylene blue, another phenotiazine, can also function as a modulatory agent on these cells (Trindade et al. 2000). The sulphated polysaccharide heparin was also capable of inhibiting the functional activity of Pgp in Lucena 1 cells and samples from leukaemic patients (Maia et al. 1996b). However, it is our experience now that not all batches of heparin are capable of such an effect and heparin activity as a modulatory agent merits further studies.

Because resistance in Lucena 1 cells could be reversed by modulators leading to chemotherapicinduced apoptosis, it seemed improbable that the resistance mechanism in these cells involved overexpression of Bcl-2, an anti-apoptotic molecule. In agreement with this supposition flow cytometry 
A

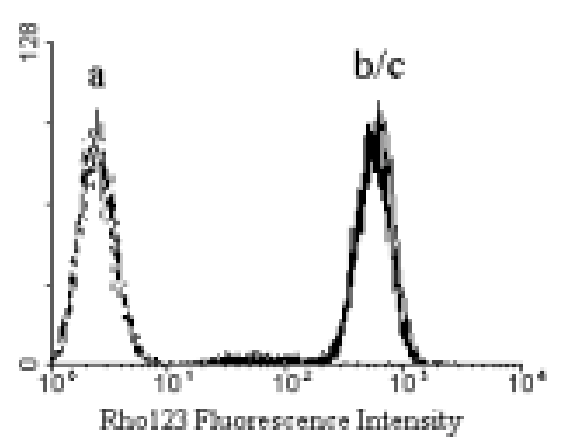

B

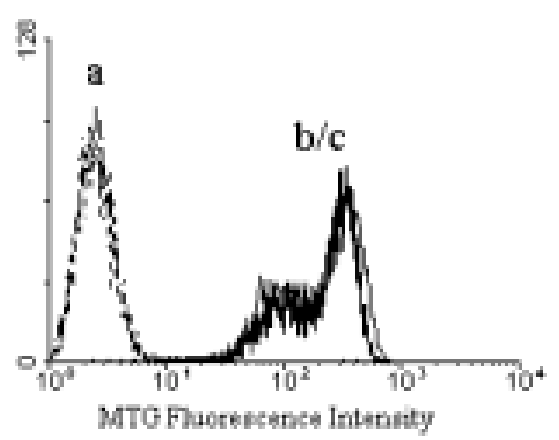

$\mathrm{C}$

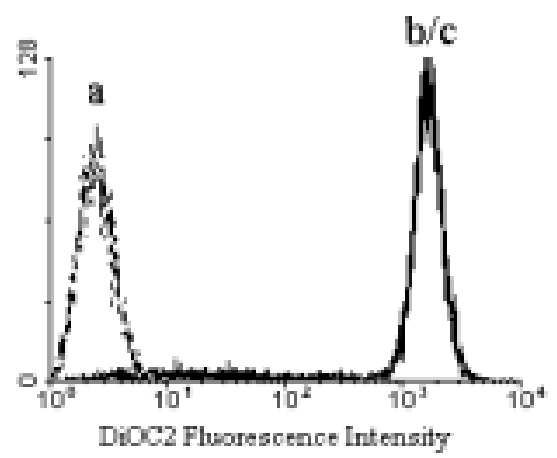

D

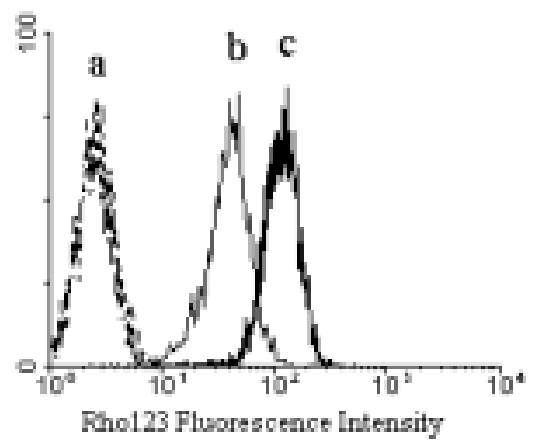

E

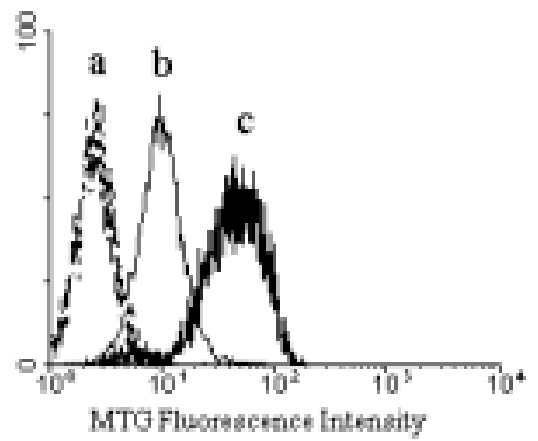

$\mathbf{F}$

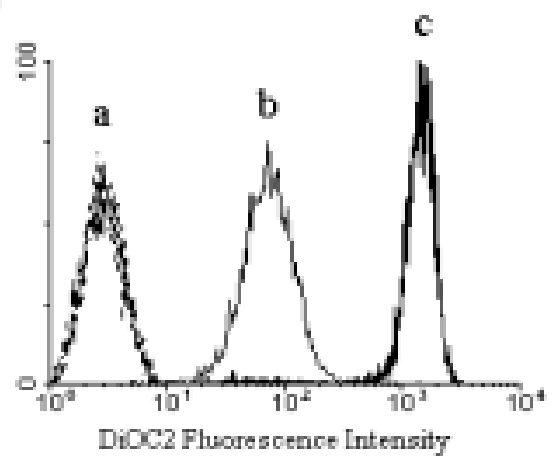

Fig. 2 - Rhodamine 123, Mitotracker Green and $\mathrm{DiOC}_{2}$ are P-Glycoprotein Substrates. K562 (A, B and C) and Lucena 1 cell lines (D, $\mathbf{E}$ and $\mathbf{F})$ were incubated in the presence of Rho $123(200 \mathrm{ng} / \mathrm{ml}-\mathbf{A}$ and D), MTG $(50 \mathrm{nM}-\mathbf{B}$ and $\mathbf{E})$ or $\mathrm{DiOC}_{2}(60 \mathrm{ng} / \mathrm{ml}-\mathbf{C}$ and $\mathbf{F})$ for 30 minutes. After this period, cells were washed with cold saline and analysed in a Flow Cytometer. Co-incubation with cyclosporin A (CSA 200 $\mathrm{ng} / \mathrm{ml}$ ) increase Rho 123 (D), MTG (E) and $\mathrm{DiOC}_{2}$ (F) fluorescence in Lucena 1 cells. The same results were obtained when cells were incubated in the presence of trifluoperazyne (TFP $5 \mu \mathrm{M}$ ) or verapamil (VP $5 \mu \mathrm{M}$ ) instead of CSA. a - autofluorescence; $\mathbf{b}$ - fluorochrome; $\mathbf{c}$ - fluorochrome plus CSA. Data are representative of at least 5 experiments. 


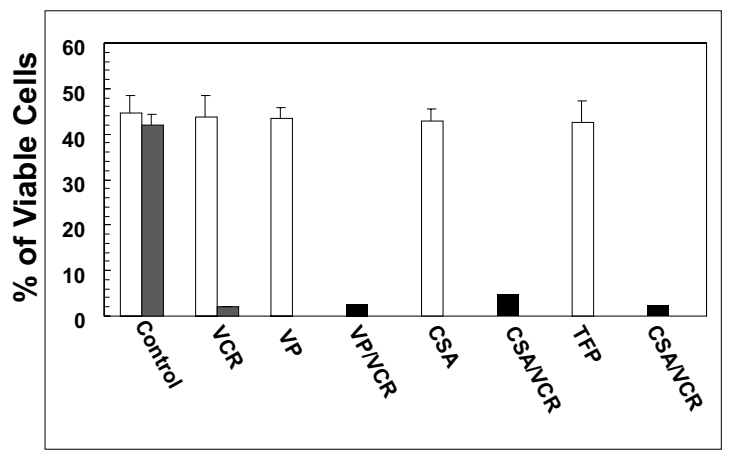

Fig. 3 - Reversal of the resistance to vincristine by MDR modulators. Lucena 1 cells were incubated for 7 days with vincristine (VCR $60 \mathrm{nM}$ ) in the presence of verapamil (VP $5 \mu \mathrm{M}$ ), cyclosporin A (CSA $200 \mathrm{ng} / \mathrm{ml}$ ) or trifluoperazyne (TFP $5 \mu \mathrm{M}$ ) and the number of remaining viable cells was counted under phase microscopy. For comparison, in black are the number of viable cells of K562 control or treated by the same time with VCR.

analysis of these cells using the anti-human Bcl2 antibody (Pharmingen) indicated that there is no difference between the parental cell line K562 and the resistant Lucena 1 cells (Wagner-Souza, K. and Echevarria-Lima, J. unpublished observations).

\section{RESISTANCE TO THAPSIGARGIN}

Calcium mobilisation from intracellular stores is a determinant step in cell signalling, including induction of apoptosis. The drug thapsigargin is capable of inhibiting the endoplasmic reticulum calcium ATPase (Sagara et al. 1992) leading to enhanced levels of cytosolic calcium as a combined result of depletion from intracellular stores and extra cellular calcium entry (Thastrup et al. 1990, Putney 1990). It has been reported that a cell line made resistant to thapsigargin was incapable of mobilising calcium and presented a MDR phenotype (Gutheil et al. 1994, Rishi et al. 1998). Conversely, MDR cell lines were also thapsigargin resistant (Gutheil et al. 1994). Lucena 1 cells did not display an increase in intracellular calcium levels following thapsigargin treatment (Orind et al.1997). Various possibilities have been advanced to explain a lack of response to thapsigargin: the diminished response to thapsigar- gin is proportional to Bcl-2 levels (Lam et al. 1994, Kuo et al. 1998, Foyouzi-Youssefi et al. 2000), but as discussed above no increased levels of Bcl-2 were observed in Lucena 1 cells; Pgp activity is capable of extruding thapsigargin, however the use of modulatory agents could not reverse the lack of response to thapsigargin in our cells (Orind et al. 1997) nor in other MDR cell lines (Gutheil et al. 1994); the diminished response to thapsigargin results from the overexpression of calcium ATPases (Hussain et al. 1995, Rishi et al. 1998), including SERCAs not normally expressed by these cells (Gutheil et al. 1994) and not capable of being inhibited by thapsigargin, this possibility, regarding Lucena 1 cells is now under investigation.

\section{RESISTANCE TO OXIDATIVE STRESS}

A number of MDR cells lines were shown to be more resistant to lipid peroxidation than their parental lines and different mechanisms have been attributed to explain this increased resistance (Benchekroun et al. 1990, Hoban et al. 1992, Hill et al. 1995, Lenehan et al. 1995, Mazzanti et al. 1995, Kühl et al. 1997). Bcl-2 and members of its family are powerful antioxidant agents and may be augmented in MDR cell lines. Similarly, an increased expression of antioxidant enzymes such as glutathione peroxidase or high levels of scavengers such as a-tocopherol present in the cellular membrane have been described (Benchekroun et al. 1990, Mazzanti et al. 1995). Lucena 1 cells are more resistant to $\mathrm{H}_{2} \mathrm{O}_{2}$ and to ultraviolet-A radiation (UVA) than the parental K562 cell line. This resistance to UV is confined to the UVA spectrum and is not extensive to UVB or UVC (Trindade et al. 1999). As the preferential target of UVA is the cell membrane as opposed to the nucleus and as this radiation tends to induce lipid peroxidation via the formation of $\mathrm{H}_{2} \mathrm{O}_{2}$, it is understandable that only this radiation is ineffective on Lucena cells, which as said above, do not show increased levels of Bcl-2. On the other hand, a high catalase activity could be detected in these cells which could explain the resistance to hy- 


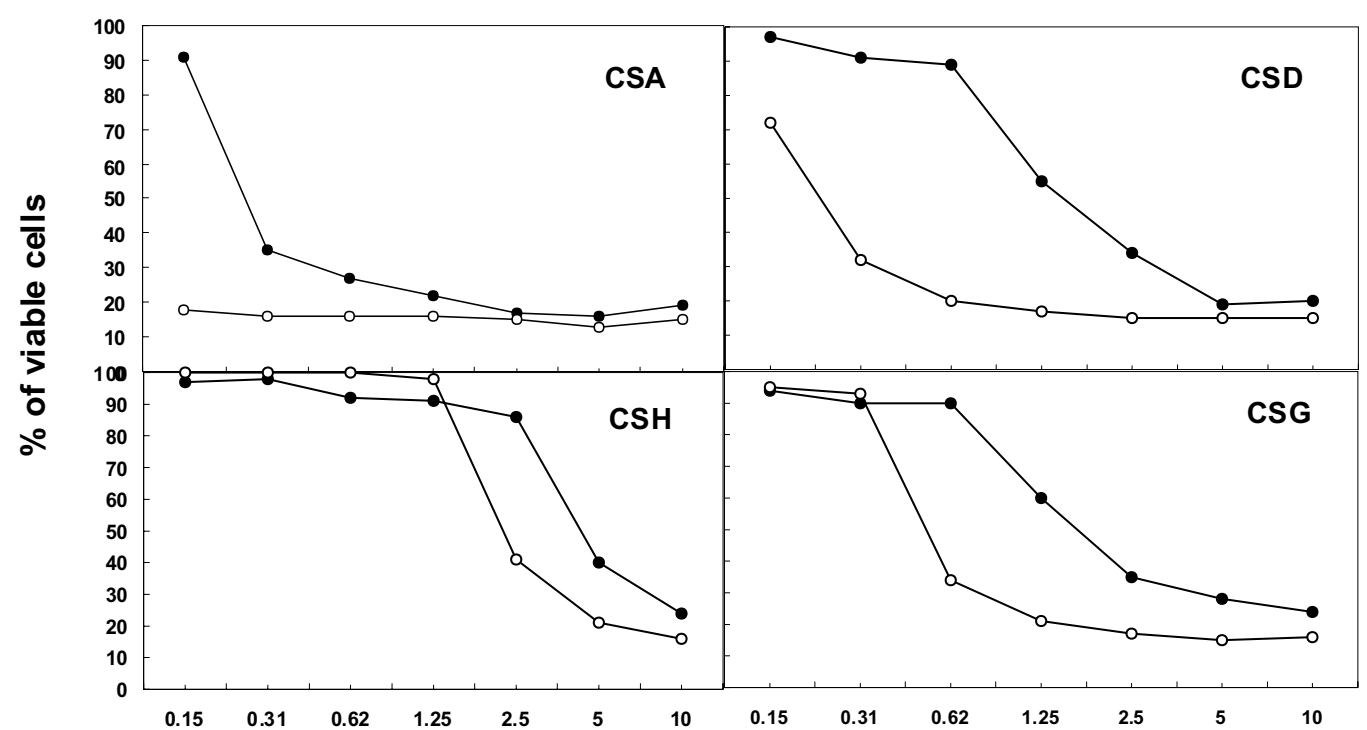

Dose $(\mu \mathrm{g} / \mathrm{ml})$

Fig. 4 - Reversal of the resistance to vincristine by cyclosporin analogues. Lucena 1 cells were incubated for 7 days with vincristine (VCR $60 \mathrm{nM}$ ) in the presence of cyclosporin A (CSA), cyclosporin D (CSD), cyclosporin $\mathrm{H}$ (CSH), cyclosporin $\mathrm{G}$ (CSG) and the number of remaining viable cells was counted under phase microscopy. Empty circles represent the effect of CSA or analogues in the resistance of cells to VCR. Black circles represent the cellular toxicity of CSA or analogues alone.

drogen peroxide (Trindade et al. 1999). However, Lucena 1 cells were shown to be susceptible to the photodynamic action of methylene blue indicating their sensitivity to the superoxide anion (Trindade et al. 2000), This results are in agreement with those of Dellinger et al. (1992) that could not find resistance to the photodynamic action of photofrin on an adriamycin induced MDR line.

\section{SENSITIVITY TO CERAMIDE}

The induction of apoptosis following oxidative stress, UVC, ionising radiation, heat shock, TNF, Fas/APO1, and chemotherapeutic agents such as daunorubicin, has been associated to the generation of ceramide. Ceramide belongs to the group of sphingosine-based lipid second messenger molecules involved in the regulation of diverse cellular responses to exogenous stimuli including apoptosis (Kolesnick \& Krönke 1998). Ceramide may result from the catabolic pathway of sphingomyelin in the plasma membrane, being found within seconds or minutes after the stimulus, or result from de novo synthesis in the endoplasmic reticulum and mitochondria, a process occurring within hours (Merrill \& Jones 1990). The hydrophobic nature of ceramide advanced the hypothesis that this product could be transported by Pgp becoming inaccessible for the deflagration of the apoptotic process. In this case, the lack of specificity of drug resistance and mechanisms not involving drugs could result from the extrusion of a toxic intermediary such as ceramide common to both pathways. Analysis of MDR cells do not support the idea of enhanced ceramide efflux by Pgp in these cells (Come et al. 1999, Lucci et al. 1999), and in agreement with 
these results both K562 and the resistant cell line Lucena 1 were equally sensitive to the effect of exogenous C2-ceramide in doses varying from $2 \mathrm{mM}$ to $2.5 \mu \mathrm{M}$ (Pinto Silva, F.E. and Meletti-de-Oliveira, M.C. unpublished observations). Nevertheless, despite the lack of increased extrusion, an enhanced conversion of ceramide to glycosylceramide can be observed in MDR cells (Lucci et al. 1999).

\section{ALTERATIONS OF THE CYTOSKELETON}

Not only the plasma membrane but also the cytoskeleton may be impaired following UVA and $\mathrm{H}_{2} \mathrm{O}_{2}$ (Milzani et al. 1997, Rafferty et al. 1997). Despite presenting a high catalase activity, the resistance of Lucena 1 cells to these treatments allied to the fact that the MDR phenotype had been induced by VCR, a drug that blocks tubulin polymerisation (Himes et al. 1976), suggested the possibility that these cells presented adaptations in their cytoskeletons. Many authors have suggested that the acquisition of the MDR phenotype is accompanied by modifications of the cytoskeleton such as increased expression of actin and/or tubulin and alterations on the organisation of stress fibres, microtubules and the Golgi complex (Lee et al. 1993, Lee 1995, Seidel et al. 1995, Erokhina et al. 1994). In agreement with these observations, Lucena 1 cells were shown to express higher levels of actin m-RNA and of the proteic subunits a and b- tubulin, when compared to the parental K562 (Trindade et al. 1998). It is still unclear the role played by the modifications observed in the cytoskeleton on the MDR phenotype.

\section{INDUCERS OF DIFFERENTIATION AND THE MDR PHENOTYPE}

Pgp is transiently expressed in bone marrow cells and its expression occurs in less differentiated cells (Uchida et al. 1996). The increased use of differentiation induction therapy for a number of tumours, specially myeloid leukaemic cells, led to the evaluation of the impact of tumour cell differentiation on the MDR phenotype (Okabe-Kado et al. 1986, Okabe-Kado et al. 1991, Patterson et al. 1996). The parental cell line used in the present study K562 cells as well as Lucena 1 cells are characterised by carrying foetal haemoglobin as defined by benzidine negative staining (Marques-Silva 1996). The use of the differentiating agents retinoic acid and phorbol ester, known to differentiate a number of leukaemic cells (Marques-Silva et al. 1990), were incapable of leading these cells lines, K562 and Lucena 1, to switch to the synthesis of adult haemoglobin whereas the chemotherapic 5-fluorouracil not only produced the haemoglobin switch but induced the extrusion of Rho 123 from K562 cells and augmented the one seen in Lucena 1 cells (Fig. 5) (Marques-Silva 1996). Work is in progress to verify if the increased extrusion observed is due to increased Pgp expression or activity, as a dissociation of these two features has been described during K562 cells differentiation (Marks et al. 1995). Alternatively it could result from the expression and activity of other pumps.

\section{INFLUENCE OF THE MDR PHENOTYPE ON THE ASSESSMENT OF MITOCHONDRIAL MASS AND TRANSMEMBRANE POTENTIAL}

Changes in mitochondrial transmembrane potential may regulate a number of cellular processes. The process of differentiation of a murine erythroleukaemia cell line involves mitochondria depolarisation (Levenson et al. 1982) and a pivotal role has been assigned to this organelle in the process of cell death (Zamzami et al. 1995, Kroemer et al. 1998). However, the relationship between the MDR phenotype and mitochondrial environment is still poorly understood. Jia et al. (1999) demonstrated that mitochondrial DNA content (mitochondrial mass) is significantly increased in a resistant cell line compared to its parental cells and proposed that this could be induced by pump expression and requirements. In this work, the authors also suggested an increased ATP generation in the resistant cell line. Many fluorescent dyes have been developed to be used as probes for the investigation of the mitochondrial membrane potential (Rho 123, JC-1, $\mathrm{DiOC}_{6}$ and CMXRos) or mitochondrial mass (Nonyl Acridine Orange or Mitotracker Green). However, all these probes are lipophilic cations what make them 


\section{A}

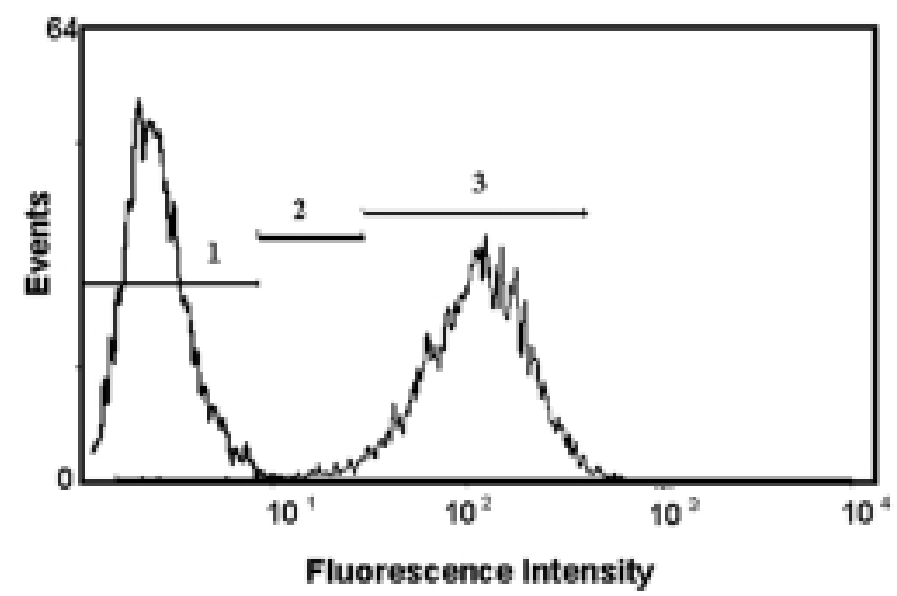

B

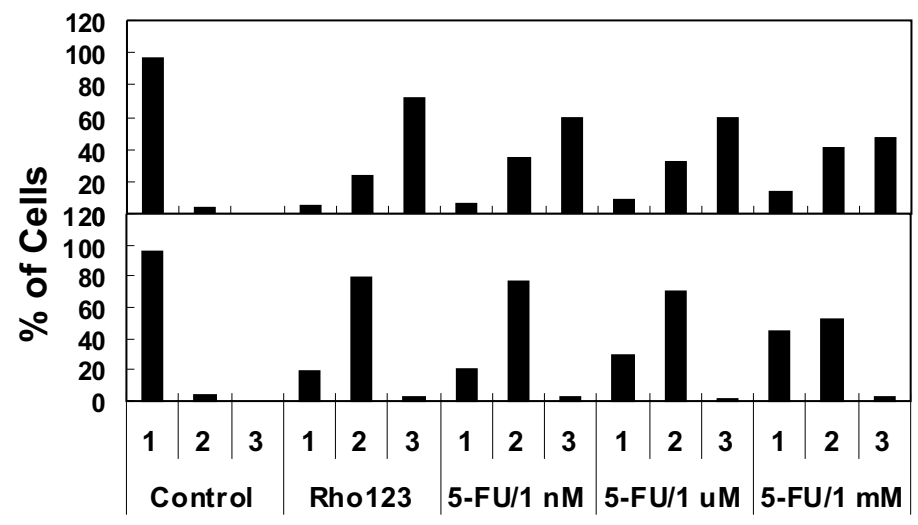

Fig. 5 - Increased extrusion of Rho 123 following 5-fluorouracil treatment. Cells were cultured with 5-fluorouracil $(1 \mathrm{nM}-1 \mathrm{mM})$ for $72 \mathrm{~h}$. After this period cells were washed and incubated with $200 \mathrm{ng} / \mathrm{ml}$ Rho 123 for $30 \mathrm{~min}$ at $37^{\circ} \mathrm{C}$, washed with cold saline and left to extrude the dye for a further $30 \mathrm{~min}$. The cells were then washed and analysed in a flow cytometer. A - Fluorescence profile of K562 cells exposed to Rho 123; region 1 represents autofluorescence of cells not exposed to Rho 123, region 3 represents the region containing the fluorescence peak of these cells exposed to Rho 123 and region 2 corresponds to the area in between. B - Upper panel: K562 cells; Lower panel: Lucena 1 cells. Region 1 represents autofluorescence in control cells, region 2 the peak of fluorescence of Lucena 1 cells and region 3 the peak of fluorescence of K562 cells.

potential candidates to be Pgp substrates. Using Lucena 1 cells it was possible to demonstrate that Mitotracker Green, a new probe for the evaluation of mitochondrial mass, is a P-gp substrate (Fig. 2). This result implies that an especial attention must be given when using fluorescent dyes to evaluate mi- 
tochondrial membrane potential and mitochondrial mass not only in MDR tumour cells but also in normal cells such as lymphocytes, thymocytes, renal cells, or any other cell type with a known Pgp activity.

\section{CONCLUDING REMARKS}

The development and characterisation of a MDR cell line not only helps in the understanding of the resistance process in tumour cells but also may contribute to the understanding of normal cells carrying the MDR phenotype. Additionally, such a cell line may be used as a tool, functioning as positive controls in systems investigating the MDR phenomenon or in systems testing new chemosensitisers.

\section{ACKNOWLEDGMENTS}

This work was supported by grants from PRONEX, Conselho Nacional de Desenvolvimento Científico e Tecnológico (CNPq) and Fundação Ary Frauzino (FAF).

\section{RESUMO}

A resistência a múltiplos fármacos é o principal obstáculo no tratamento de pacientes com câncer. O mecanismo responsável pela resistência múltipla mais bem caracterizado envolve a expressão do produto do gene MDR-1, a glicoproteína P. Entretanto, o processo de resistência tem fatores múltiplos. Estudos de mecanismos de resistência múltipla a fármacos têm dependido da análise de linhagens celulares tumorais que foram selecionadas e apresentam reatividade cruzada a uma ampla faixa de agentes antitumorais. Este trabalho caracteriza uma linhagem celular com múltipla resistência a fármacos, selecionada originalmente pela resistência ao alcalóide de Vinca vincristina e derivado da linhagem eritro-leucêmica K562. Esta linhagem celular, denominada Lucena 1, super-expressa a glicoproteína $\mathrm{P}$ e tem sua resistência revertida pelos quimio-sensibilizantes verapamil, trifluoperazina e ciclosporinas A, D e G. Ademais, demonstramos que o azul de metileno era capaz de reverter parcialmente a resistência nesta linhagem celular. Em contraste, o uso de 5-flúoruracil aumentava a resistência de Lucena 1. Adicional- mente aos quimioterápicos, células Lucena 1 eram resistentes radiação ultra-violeta A e peróxido de hidrogênio e deixavam de mobilizar o cálcio intra-celular quando se usava tapsigargina. Mudanças no cito-esqueleto desta linhagem foram também observadas.

Palavras-chave: resistência múltipla a fármacos, leucemia, glicoproteína $\mathrm{P}$, quimiossensibilizantes.

\section{REFERENCES}

Benchekroun MN, Catroux P, Montaudon D \& Robert J. 1990. Development of mechanisms of protection against oxidative stress in doxorubicinresistant rat tumoral cells in culture. Free Radic Res Commun 11: 137-144.

Boer R \& Gekeler V. 1995. Chemosensitizer in tumor therapy: new compounds promise better efficacy. Drugs Future 20: 499-509.

Brindeiro PA. 1999. Caracterização de aspectos bioquímicos e moleculares de linhagem eritroleucêmica Lucena 1-K562 envolvidos com o fenótipo MDR. MSc Thesis, Universidade Federal do Rio de Janeiro, Brazil.

Cole SpC, Bhardwaj G, Gerlach JH, Mackie Je, Grant CE, Almquist KC, Stewart AJ, Kurz EU, Duncan AMV \& Deeley RG. 1992. Overexpression of a transporter gene in a multidrug-resistant human lung cancer cell line. Science 258: 1650-1654.

Cole SPC, Sparks Ke, Fraser K, Loe DW, Grant CE, Wilson GM \& Deeley RG. 1994. Pharmacological characterization of multidrug resistant MRP-transfected human tumor cells. Cancer Res 54: 59025910 .

Come MG, Bettaieb A, Skladanowski A, Larsen AK \& LAurent G. 1999. Alteration of the daunorubicin-triggered sphingomyelin-ceramide pathway and apoptosis in MDR cells: influence of drug transport abnormalities. Int J Cancer 81: 580-587.

Dalton WS. 1997. Mechanisms of drug resistance in hematologic malignancies. Sem Hematol 34: Suppl. $5,3-8$

Dellinger M, Moreno G, Salet C, Tapiero H \& LamPIDIS TJ. 1992. Cytotoxic and photodynamic effects 
of Photofrin on sensitive and multidrug-resistant Friend leukaemia cells. Int J Radiat Biol 62: 735-741.

Denis-Gay M, Petit J-M, Mazat J-P \& Ratinaud M-H. 1998. Modifications of oxido-reductase activities in adriamycin-resistant leukaemia K562 cells. Biochem Pharmacol 56: 451-457.

Erokhina M, Shtil AA, Shushanov SS, Sidorova TA \& Stavrovskaya AA. 1994. Partial restoration of the actin cytoskeleton in transformed Syrian hamster fibroblasts selected for low levels of 'typical' multidrug resistance. FEBS Letters 341: 295-298.

FoRD JM \& HAIT WN. 1990. Pharmacology of drugs that alter multidrug resistance in cancer. Pharmacol Rev 42: 155-199.

Foyouzi-Youssefi R, Arnaudeau S, Borner C, KelLEy WL, Tschopp J, Lew DP, Demaurex N \& Krause KH. 2000. Bcl-2 decreases the free $\mathrm{Ca}^{2+}$ concentration within the endoplasmic reticulum. Proc Natl Acad Sci USA 97: 5723-5728.

Gottesman MM \& Pastan I. 1993. Biochemistry of multidrug resistance mediated by the multidrug transporter. Annu Rev Biochem 62: 385-427.

Gros P, Croop J \& Housman D. 1986. Mammalian multidrug resistance gene: Complete cDNA sequence indicates strong homology to bacterial transport proteins. Cell 47: 371-380.

Gutheil JC, Hart SR, Belani CP, Melera PW \& HusSAIN A. 1994. Alterations in $\mathrm{Ca}^{2+}$ transport ATPase and P-glycoprotein expression can mediate resistance to thapsigargin. J Biol Chem 269: 7976-7981.

HigGins CF. 1992. ABC transporters: from microorganisms to man. Annu Rev Cell Biol 8: 67-113.

Hill HZ, Hill GJ, CieszKa K, Azure M, Chowdhary I \& SAYRE RM. 1995. A multitherapy resistance factor from melanoma reveals that killing by near UV is different from genotoxic agents. Photochem Photobiol 61: $479-483$.

Himes RH, Kersey RN, Heller-Bettinger J \& SAmSON FE. 1976. Action of the vinca alkaloids vincristine, vinblastine and desacetyl vinblastine amide on microtubules in vitro. Cancer Res 36: 3798-3802.
Hoban PR, Robson CN, Davies SM, Hall AG, CatTAN AR, HickSON ID \& HARRIS AL. 1992. Reduced topoisomerase II and elevated a class glutathione Stransferase expression in a multidrug resistant $\mathrm{CHO}$ cell line highly cross-resistant to mitomicin C. Biochem Pharmacol 43: 685-693.

Hussain A, Garnett C, Klein MG, Tsai-Wu JJ, SCHNeIDER MF \& INESI G. 1995. Direct involvement of intracellular $\mathrm{Ca}^{2+}$ transport ATPase in the development of thapsigargin resistance by Chinese hamster lung fibroblasts. J Biol Chem 270: 1214012146 .

Jia L, Liu K-Z, Newland AC, Mantsch HH \& Kelsey SM. 1999. Pgp-positive leukaemic cells have increased mtDNA but no increased rate of proliferation. Brit J Haematol 107: 861-869.

JuLiano RL \& LiNG V. 1976. A surface glycoprotein modulating drug permeability in Chinese hamster ovary cell mutants. Biochim Biophys Acta 455: 152162.

Juranka PF, Zastawny RL \& Ling V. 1989. P-glycoprotein: multidrug-resistance and a superfamily of membrane-associated transport proteins. FASEB J 3: 2583-2592.

KOLESNICK RN \& KRÖNKE M. 1998. Regulation of ceramide production and apoptosis. Annu Rev Physiol 60: $643-665$.

Kroemer G, Dallaporta B \& Resche-Rigon M. 1998. The mitochondrial death/life regulator in apoptosis and necrosis. Annu Rev Physiol 60: 619-642.

Kühl JS, Krajewski S, Durán GE, Reed JC \& Sikic BI. 1997. Spontaneous overexpression of the long form of the Bcl-x protein in a highly resistant P388 leukaemia. Br J Cancer 75: 268-274.

Kuo TH, Kim HR, Zhu L, Yu Y, Lin HM \& Tsang W. 1998. Modulation of cytoplasmic reticulum calcium pump by Bcl-2. Oncogene 17: 1903-1910.

Lam M, Dubyak G, Chen L, Nunez G, MiesFELD RL \& Distelhorst CW. 1994. Evidence that BCL-2 represses apoptosis by regulating endoplasmic reticulum-associated $\mathrm{Ca}^{2+}$ fluxes. Proc Natl Acad Sci 91: 6569-6573. 
Lee CH, Bradley G, Zhang JT \& Ling V. 1993. Differential expression of P-glycoprotein genes in primary rat hepatocyte culture. J Cell Physiol 157: 392-402.

LEE W-P. 1995. Purification and characterization of tubulin from parental and vincristine-resistant HOB1 lymphoma cells. Arch Biochem Biophys 319: 498503.

Lenehan PF, Gutierrez PL, Wagner JL, Milak N, Fisher GR \& Ross DD. 1995. Resistance to oxidants associated with elevated catalase activity in HL-60 leukemia cells that overexpress multidrug-resistance protein does not contribute to the resistance to the resistance to daunorubicin manifested by these cells. Cancer Chemother Pharmacol 35: 377-386.

Levenson R, Macara IG, Smith RL, Cantley L \& Housman D. 1982. Role of mitochondrial membrane potential in the regulation of murine erythroleukemia cell differentiation. Cell 28: 855-863.

List AF, Spier C, Greer J, Woff S, Hutter J, Dorr R, Salmon S, Futscher R, Baier M \& Dalton W. 1993. Phase I/II trial of cyclosporine as a chemotherapy-resistance modifier in acute leukemia. J Clin Oncol 11: 1652-1660.

Lucci A, Giuliano AE, Han TY, Dinur T, Liu YY, Senchenkov A \& CABot MC. 1999. Ceramide toxicity and metabolism differ in wild-type and multidrug-resistant cancer cells. Int J Oncol 15: 535-540.

Maia RC, Silva EAC, Harab RC, Lucena M, Pires V \& RumuaneK VM. 1996a. Sensitivity of vincristine-sensitive K562 and vincristine resistant Lucena-1 cells to anthracyclines and reversal of multidrug resistance. Braz J Med Biol Res 29: 467-472.

Maia RC, Wagner K, Cabral RH \& RumjaneK VM. 1996b. Heparin reverses rhodamine 123 extrusion by multidrug resistant cells. Cancer Lett 106: 101-108.

Marks DC, Davey MW, Davey RA \& Kidman AD. 1995. Expression of multidrug resistance in response to differentiation in the K562 leukaemia cell line. Biochem Pharmacol 50: 475-480.

Marques-Silva VM. 1996. Efeito de moduladores da diferenciação celular no processo de resistência a múltiplas drogas. PhD Thesis, Universidade Federal Fluminense, Brazil.
Marques-Silva VM, de Souza MHO, Teixeira MCL, Arcuri RA \& Rumuanek VM. 1990. Myeloid leukemia differentiation by phorbol ester and retinoic acid: a practical approach. J Clin Lab Anal 4: 342-349.

Matsumoto Y, Takano H \& Fojo T. 1997. Cellular adaptation to drug exposure: evolution of the drugresistant phenotype. Cancer Res 57: 5086-5092.

Mazzanti R, Fantappiè O, FAbrizio P \& Relli P. 1995. Susceptibility to lipid peroxidation of human hepatocellular carcinoma cell lines with different levels of multiple drug-resistant phenotype. Lab Inv 73: 419-423.

Merrill AH JR \& Jones DD. 1990. An update of the enzymology and regulation of sphingomyelin metabolism. Biochim Biophys Acta 1044: 1-12.

Milzani A, Dalledonne I \& Colombo R. 1997. Prolonged oxidative stress on actin. Arch Biochem Biophys 2: 267-274.

Mizuno K, Furuhashi Y, Misawa T, Iwata M, KawaI M, KikKawa F, Kano T \& Tomoda Y. 1992. Modulation of multidrug resistance by immunosupressive agents: cyclosporin analogues, FK506 and Mizoribine. Anticancer Res 12: 21-25.

Modrak DE, Draper MP \& Levy SB. 1997. Emergence of different mechanisms of resistance in the evolution of multidrug resistance in murine erythroleukemia cell lines. Biochem Pharmacol 54: 1297-1306.

Muller M, Meijer C, Zaman GJR, Borst P, Scheper RJ, Mulder NH, de VRies EGE \& Jansen PLM. 1994. Overexpression of the gene encoding the multidrug resistant-associated protein results in increased ATP-dependent glutathione S-conjugate transport. Proc Natl Acad Sci 91: 13033-13037.

Neefjes JJ, Momburg F \& Hammerling GJ. 1993. Selective and ATP-dependent translocation of peptides by the MHC-encoded transporter. Science 261: 769771.

NeYFAKH AA. 1988. Use of fluorescent dyes as molecular probes for the studies of multidrug resistance. Exp Cell Res 174: 168-176.

OKabe-Kado J, Hayashi M, Honma Y \& Hozumi M. 
1986. Enhancement by hemin of the sensitivity of K562 human leukemic cells to $1-\beta$-arabinofuranosylcytosine. Cancer Res 46: 1239-1243.

Okabe-Kado J, Hayashi M, Honma Y, Hozumi M \& Tsuruo T. 1991. Inhibition by erythroid differentiation factor (activin A) of P-glycoprotein expression in multidrug-resistant human K562 erythroleukemia cells. Cancer Res 51: 2582-2586.

Orind M, Wagner-Souza K, Maia RC \& RumjaneK VM. 1997. Modulation of P-glycoprotein on tumour cells. In: Sotelo JR \& Benech JC (Ed.): Calcium and cellular metabolism: transport and regulation. New York: Plenum Press, p. 117-124.

Patterson KK, Beckman BS, Klotz DM, Mallia CM \& JETER JR. 1996. Dexniguldipine hydrochloride, a protein-kinase-C-specific inhibitor, affects the cell cycle, differentiation, P-glycoprotein levels, and nuclear protein phosphorylation in Friend erythroleukemia cells. J Cancer Res Clin Oncol 122: 465475 .

Pétriz J \& Garcia-López J. 1997. Flow cytometric analysis of $\mathrm{P}$-glycoprotein function using rhodamine 123. Leukemia 11: 1124-1130.

Putney JW. 1990. Capacitative calcium entry revisited. Cell Calcium 11: 611-624.

RAFFERTY NS, RAFFERTY KA \& Zigman S. 1997. Comparative response to UV irradiation of cytoskeletal elements in rabbit and skate lens epithelial cells. Curr Eye Res 6: 310-319.

Rishi AK, Yu M, Tsai-Wu JJ, Belani CP, Fontana JA, Baker DL, Periasamy M \& Hussain A. 1998. Gene amplification and transcriptional upregulation of the sarco/endoplasmic reticulum $\mathrm{Ca}^{2+}$ transport ATPase in thapsigargin-resistant hamster smooth muscle cells. Nucleic Acids Res 26: 4529-4537.

Rumjanek VM, Lucena M, Campos MM, MarquesSilva VM \& Maia RC. 1994. Multidrug resistance in leukemias: the problem and some approaches to its circumvention. Ciencia Cult 46: 63-69.

Sagara Y, Fernandez-Belda F, de Meis L \& Inesi G. 1992. Characterization of the inhibition of intracellular $\mathrm{Ca}^{2+}$ transport ATPases by thapsigargin. J Biol Chem 267: 12606-12613.
Scheffer GL, Wijngaard PlJ, Flens MJ, IzQuierdo MA, Slovak ML, Pinedo HM \& SchePer RJ. 1995. The drug resistance-related protein LRP is the major vault protein. Nat Med 1: 578-582.

Seidel A, Hasmann M, Loser R, Bunge A, Schaefer B, Herzig I, Steidtmann K \& Dietel M. 1995. Intracellular localisation, vesicular accumulation and kinetics of daunorubicin in sensitive and multidrugresistant gastric carcinoma EPG85-257 cells. Virchows Arch 426: 249-256.

Tanaka K, Hirai M, Tanigawara Y, Yasuhara M, Hori R, Ueda K \& InUi K. 1996. Effect of Cyclosporin A analogues and FK506 on transcellular transport of Daunorubicin and Vimblastine via Pglycoprotein. Pharmaceutical Res 13: 1073-1077.

Thastrup O, Cullen PJ, Drobak BK, Hanley MR, \& DAwson AP. 1990. Thapsigargin, a tumor promoter, discharges intracellular $\mathrm{Ca}^{2+}$ stores by specific inhibition of the endoplasmic reticulum $\mathrm{Ca}^{2+}$ ATPase. Proc Natl Acad Sci USA 87: 2466-2470.

Trindade GS, Capella LS, Leite AC, de Freitas MS, Moura Neto V, Capella MAM \& Rumjanek VM. 1998. Differences in sensitivity to oxidative agents of a multidrug resistant cell line overexpressing Pglycoprotein. In: Proceedings of $17^{\text {th }}$ International Cancer Congress. Bologna. Monduzzi Editore, p. 179-182.

Trindade GS, Capella MAM, Capella LS, AffonsoMitTidieri OR \& RumJanek VM. 1999. Differences in sensitivity to UVC, UVB and UVA radiation of a multidrug-resistant cell line overexpressing P-glycoprotein. Photochem Photobiol 69: 694-699.

Trindade GS, Farias SL, Rumuanek VM \& Capella MAM. 2000. Methylene blue reverts multidrug resistance sensitivity of multidrug resistance cells to this dye and its photodynamic action. Cancer Lett 151: $161-167$.

Tsuruo T, Iida H, Tsukagoshi S \& Sakurai Y. 1981. Overcoming of vincristine resistance in P388 leukemia "in vivo" and "in vitro" through enhanced cytotoxicity of vincristine and vinblastine by verapamil. Cancer Res 41: 1967-1972.

Tsuruo T, Iida $\mathrm{H}$, Оhкоchi E, Tsukagoshi $\mathrm{S} \&$ 
SAKURAI Y. 1983. Establishment and properties of a vincristine-resistant human myelogenous leukemia K562. Jpn J Cancer 74: 751-758.

Uchida N, Combs J, Chen S, Zanjani E, Hoffman R \& Tsukamoto A. 1996. Primitive human hematopoietic cells displaying differential efflux of the rhodamine 123 dye have distinct biological activities. Blood 88: 1297-1305.
Yanovich S, Hall RE \& Gewirtz DA. 1989. Characterization of a K562 multidrug-resistant cell line. Cancer Res 49: 4499-4501.

Zamzami N, Marchetti P, Castedo M, Zanin C, Vayssiere JL, Petit PX \& Kroemer G. 1995. Reduction in mitochondrial potential constitutes an early irreversible step of programmed lymphocyte death in vivo. J Exp Med 181: 1661-1672. 